\title{
Influence of Zeatin and Gibberellin on Adenosine-3',5'-Cyclic Monophosphate Levels of Impatiens Leaves
}

\author{
U. Kull and B. Kühn \\ Biologisches Institut der Universität Stuttgart
}

(Z. Naturforsch. 30 c, 69-72 [1975] ; received August 21/October 4, 1974)

Adenosine-3',5'-Cyclic Monophosphate, Cytokinin, Gibberellin, Theophylline, Impatiens

\begin{abstract}
The content of adenosine- $3^{\prime}, 5^{\prime}$-cyclic monophosphate (cAMP) in leaves of Impatiens sultani Hook. was measured by a protein-binding assay. A preceding administration of the natural cytokinin zeatin causes a diminution of the cAMP level. Administration of gibberellin (GA, does not bring about any variations. There is no indication that cAMP is acting as a secondary messenger of either phytohormone. Theophylline does not increase the content of cAMP found in the leaves.
\end{abstract}

Results regarding the occurrence and function of adenosine-3',5'-cyclic monophosphate (cAMP) in higher plants are still confused and we do not yet understand its possible role and action-mechanism in plant cells. Using different methods, cAMP has been identified in diverse species and organs of higher plants. By some investigators, with an assay using a cAMP-binding protein ${ }^{1}$, the occurrence of the cyclic nucleotide was demonstrated in several tissues, including soybean callus ${ }^{2}$, maize seedlings ${ }^{3}$, phloem sap 4 , Avena etioplasts ${ }^{5}$ and leaves as well as other tissues of various species ${ }^{6}$. Using the activation of a protein kinase as an assay, cAMP was found in lettuce seeds ${ }^{7}$ and in diverse tissues, including leaves from Chinese cabbage ${ }^{8}$. By a spectrophotometric method cAMP was determined in Phaseolus $^{\circ}$. Isolation of the radioactive cyclic nucleotide after administration of labelled adenine or adenine derivatives was used as a test for cAMP from seeds ${ }^{10,11}$ and coleoptiles ${ }^{12,13}$.

No cAMP could be found in some species by Brown and Newton ${ }^{\circ}$, by some investigators in barley ${ }^{14,15}$ and most recently by Amrhein ${ }^{16}$ in any of the higher plants he examined. In algae, cAMP was demonstrated to be present in Chlamydomonas $^{17}$ and Euglena ${ }^{18,19}$. There is not doubt about the occurrence and some of the functions of the cyclic nucleotide in animals and fungi ${ }^{20,21}$. Therefore, phylogenetic reflections would suggest its presence also in higher plants, but the function(s) may be very different. A role for CAMP as a secondary messenger of phytohormones has been re-

Requests for reprints should be sent to Dr. U. Kull, Biologisches Institut der Universität Stuttgart, D-7000 Stuttgart 60, Ulmer Str. 227. peatedly suggested, since cAMP mimics some hormonal effects, and hormones are reported to have an influence on the cAMP levels in plant tissues (for gibberellin e.g. ${ }^{10,22-26}$; for auxins e. g. ${ }^{12-13,27,28}$ ). In some publications ${ }^{29,30}$ a similar role for cAMP concerning cytokinins was suspected, too. Other authors ${ }^{14,31-33}$ could not find any indications of a mode of action as a secondary messenger, so the relations between phytohormones and cAMP remain rather obscure ${ }^{33}$.

We have investigated the influence of the natural cytokinin zeatin on the content of cAMP in leaves. Some more experiments were carried out by administration of gibberellin.

\section{Material and Methods}

Leaves of a clone of Impatiens sultani Hook. were used. Some experiments were made with leaves from Coleus blumei Benth., but there were great deviations caused by disturbances in the measurements.

Fresh leaf tissues after administration of the phytohormone or water (for controls) were worked up as described ${ }^{2.6}$ and after centrifugation $(24000 \times \mathrm{g}$ for $15 \mathrm{~min}$ ) the cAMP was determined in the supernatant by the isotope-dilution method 1, 34 (Boehringer). Samples were counted on a Packard scintillation counter. Each measurement was normally run in triplicate using different dilutions of the extract. Two sets of standards were usually run ${ }^{2}$.

The validity of the assay was established by the following procedures: 1 . Addition of known amounts of cold cAMP and in other experiments of $\left[{ }^{3} \mathrm{H}\right] \mathrm{cAMP}$ to leaf homogenates. In these experiments the quantity of endogenous cAMP and the 
5 or $10 \mathrm{pM}$ of added cAMP were additive with a deviation of $\pm 8 \%$. - 2. Treatment of leaf homogenates with beef heart phosphodiesterase ${ }^{2}$ (Boeh. ringer) (incubation time in most experiments 3 hours, sometimes 4 hours, which gave the same results). Then, no cAMP could be found. After subsequent addition of known concentrations of the cyclic nucleotide between 90 and $97 \%$ of the cAMP added was found again. - It was also shown, that $4.56 \times 10^{-7} \mathrm{M}$ zeatin had no effect on the binding of $\left[{ }^{3} \mathrm{H}\right]$ cAMP to the binding protein.

In some experiments the protein content of leaf tissue was determined as a reference standard by Kjeldahl and biuret methods.

The administration of zeatin (Sigma Chem. Comp.) was performed in the following ways:

1. Leaves or leaf-halves of identical size from the same plant were fed zeatin for $\mathbf{2 0}$ hours from solutions through petioles. Then, the quantity of zeatin taken up per $g$ fresh-weight could be roughly calculated.

2. Leaf-discs from one leaf were held floating for 20 hours on zeatin solutions of different concentrations $(0.5 \mathrm{ppm}=2.28 \mu \mathrm{M} / 1 ; 2 \mathrm{ppm}=9.12$ $\mu \mathrm{M} / 1 ; 10 \mathrm{ppm}=45.6 \mu \mathrm{M} / \mathrm{l})$. As controls, other discs from the same leaf were maintained floating on water.

3. Leaf-discs from one leaf were vacuum-infiltrated with zeatin solutions of different concentrations and subsequently held immersed for 3 hours or 1 hour in the respective solution. Corresponding discs were similarly treated with water.

Some experiments were carried out applying gibberellin ( $\mathrm{GA}_{3}$; Merck, Darmstadt) by the same methods.

According to Amrhein ${ }^{16}$ there is no unequivocal proof that the substance (s) measured by the method which we made use of is identical wich cAMP. The statement of the disintegration of the substance by cyclic nucleotide phosphodiesterase is an indication of the presence of cAMP, but may be ambiguous, too. A more reliable method seems to be the protein kinase assay. Applying this technique there were found levels of cAMP in different tissues ${ }^{8}$ of the same order as we have measured. The content found by other workers with different methods, including ours $6, \%$, are also in good agreement with our data. But, to be precise, in the representation of our results the term "cAMP" simply stands for "the substance(s) measured by the protein binding assay as cAMP".

Leaves from sterile seedlings yielded similar values of cAMP levels as nonsterile material ${ }^{*}$. Therefore it may be concluded, that the cAMP measured is not due to microbial contamination.

\section{Results}

First, it was shown that young (apical) leaves have a higher content of cAMP than older (basal) leaves (Table I).

Table I. Levels of cAMP in different leaves from one plant of Impatiens sultani (in pM/mg fresh-weight; three indepen. dent experiments were run).

old leaf (basal)

$0.22 \pm 0.03$

middlesized leaf

$0.27 \pm 0.02$

young leaf (apical, not fully expanded)

$0.92 \pm 0.10$

A diminuation with increasing age of the tissue is in agreement with findings concerning different materials, including leaves of some species 3, 6. 9 . All concentrations measured are in the range of $0.12-1.3 \mathrm{pM} / \mathrm{mg}$ fresh-weight or $4-33 \mathrm{pM} / \mathrm{ml}$ protein-N. In middlesized leaves, as used for the experiments with the phytohormones, we found $0.25-0.6 \mathrm{pM} / \mathrm{mg}$ fresh-weight.

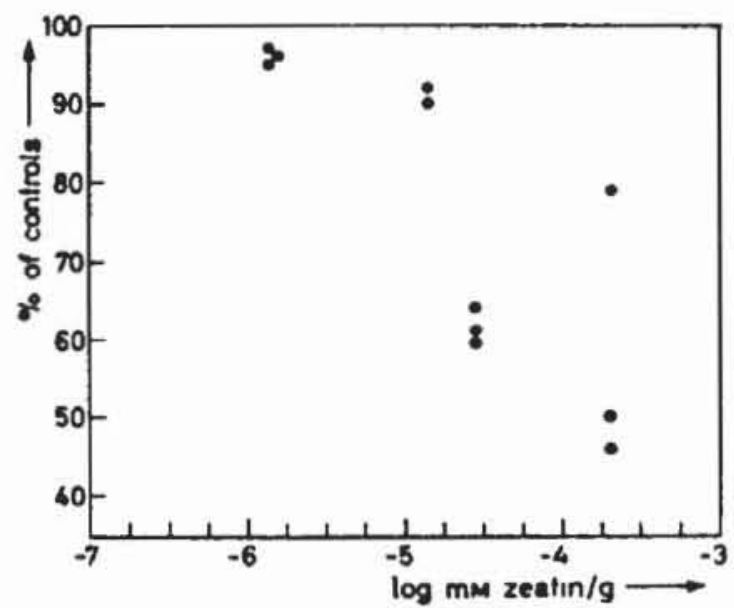

Fig. 1. Content of cAMP in leaves of Impatiens after administration of different quantities of zeatin (Method 1) as percent of cAMP levels of controls. Each point represents one measurement, run in triplicate.

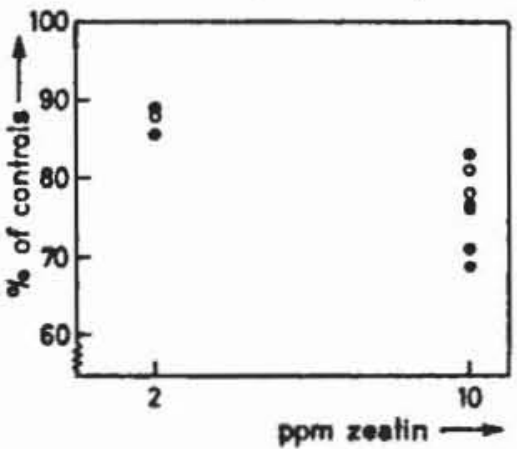

Fig. 2. Content of cAMP in leaf-discs of Impatiens after floating for 20 hours on solutions of different zeatin concentrations (Method 2), as percent of cAMP levels of controls. Full circles: Only zeatin administered; open circles: Zeatin together with theophylline administered. Each point represents the sverage of usually three independent measure. ments. 


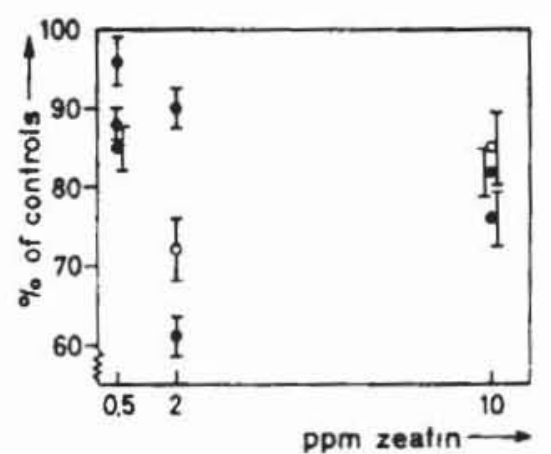

Fig. 3. Content of cAMP in leaf discs of Impatiens 3 hours after vacuum-infiltration of different concentrations of zeatin (Method 3), as percent of cAMP levels of controls. Full and open circles as in Fig. 2. Each point represents the average of three independent measurements.

By supplying zeatin the level of cAMP is diminished, as shown in Figs 1-3. Application of the vacuum-infiltration method caused an effect after 3 hours of action of the hormone and infiltration of a $0.5 \mathrm{ppm}$ solution. A reduction of the time to 1 hour $(0.5 \mathrm{ppm}$ or $2 \mathrm{ppm}$ zeatin infiltrated) produced no significant effect whatsoever.

Cytokinin effects may vary according to season or daylength ${ }^{35}$, therefore we kept plants at light periods of 16 hours and 8 hours. There was no influence of these different daylengths on the diminution of cAMP content caused by zeatin.

In all experiments performed with gibberellin we could find no effect of this hormone on the cAMP levels of leaves (administered: $1.4 \times 10^{-2}$ and $23.2 \times 10^{-3} \mu \mathrm{M} / \mathrm{g}$ fresh-weight) or of leaf discs $(2,10$, and $100 \mathrm{ppm})$.

Investigations adding theophylline (500 ppm; $1000 \mathrm{ppm})$ as a possible inhibitor of the cyclic nucleotide phosphodiesterase were carried out in order to see if the decrease of the cAMP content caused by the cytokinin would be eliminated or at least diminished. But application of theophylline alone did not raise the cAMP levels measured, and, as shown in Figs 2 and 3, there is no clear influence of the presumed inhibitor in the leaves fed with zeatin.

\section{Discussion}

The influence of zeatin on cAMP levels becomes effective at hormone concentrations of the same

1 A. G. Gilman, Proc. Nat. Acad. Sci. U.S. 67, 305 [1970].

2 N. J. Brewin and D. H. Northcote, J. Exp. Bot. 24, 881 [1973].

R. Bachofen, Plant Sci. Lett. 1, $447,[1973]$.

- D. Becker and H. Ziegler, Planta 110, 85 [1973]. order of magnitude as required for the action of the hormone on respiration ${ }^{35}$. Raising the hormone concentrations causes a more pronounced decrease of the cAMP content. There is no optimum-concentration, as found for the influence of zeatin on respiration ${ }^{36}$, photosynthesis ${ }^{37}$, and on the lipid fatty acids of leaves ${ }^{38}$. Our results are contrary to those of Brewin and Northcote ${ }^{2}$, who - applying the same method - measured an increase in cAMP concentration in soybean callus 20 hours after cytokinin administration. Our data do not support the hypothesis that cAMP is a secondary messenger for cytokinins or for gibberellins. Theophylline apparently is not effective as an inhibitor of cyclic nucleotide phosphodiesterase in our experiments. This is in agreement with findings of some authors 14, 16, 25, 39, but opposed to those of ohers ${ }^{30}, 33,40,41$.

We found, that zeatin causes a diminution of the cAMP level. Moreover, it was demonstrated ${ }^{\mathbf{4}}$, that the cAMP content of Jerusalem artichoke tubers rapidly declined when dormant tissue was activated. Several zeatin effects may be interpreted best as an enhancement of anabolic processes without a fundamental alteration of the metabolic situation ${ }^{43}$. Therefore, it seems possible that cytokinins and cAMP are antagonists in some relations. On the other hand in recent publications $\mathbf{4 4 , 4 5}$ cAMP was established to be a competitive inhibitor of a specific plant ribonucleotide phosphohydrolase; cytokininribosides act as noncompetitive inhibitors of this enzyme. There are doubts about the regulatory significance of these negative controls in vivo, but effects of cAMP and cytokinins, which are analogous in some respect, can be seen in the same materials. Perhaps, cAMP is maintaining a certain metabolic rate and cytokinins are enhancing anabolic processes. This enhancement seems to be connected with a diminution of cAMP levels.

The investigations were kindly supported by the Deutsche Forschungsgemeinschaft. We are indebted to Prof. K. Köhler for placing the Packard scintillation counter to our disposal and to Mr. P. Cleary for correction of the English text.

- A. R. Wellburn, J. P. Ashby, and F. A. M. Wellburn, Biochim. Biophys. Acta 320, 363 [1973].

- B. Kessler and R. Levinstein, Biochim. Biophys. Acta 343,156 [1974]. 
7 A. Pradet, Ph. Raymond, and A. Narayanan, C. R. Acad. Sci. Ser. D, 275, 1987 [1972].

- P. Raymond, A. Narayanan, and A. Pradet, Biochem. Biophys. Res. Commun. 53, 1115 [1973].

- E. G. Brown and R. P. Newton, Phytochemistry 12 2683 [1973].

10 C. J. Pollard, Biochim. Biophys. Acta 201, 511 [1970].

11 S. Azhar and C. R. K. Murti, Biochem. Biophys. Res. Commun. 43, 58 [1971].

12 D. Salomon and J. P. Mascarenhas, Life Sci. 10, 879 [1971].

13 B. Janistyn, Z. Naturforsch. 27 b, 273 [1972].

14 R. A. B. Keates, Nature 24h 355 [1973].

is R. Alvarez. Th. C. Moore, and J. Vandepeute. Plant Physiol. 53, 144 [1974].

16 N. Amrhein, Planta 118, 241 [1974].

17 N. Amrhein and Ph. Filner, Proc. Nat. Acad. Sci. U.S. 70, 1099 [1973].

so J. J. Keirns, B. Carriet, J. Freeman, J. M. Fisenstadt, and M. W. Bitensky, Life Sci. 13, 287 [1973].

10 P. Nicolas and V. Nigon, C. R. Acad. Sci., Ser. D, 277, 1641 [1973].

20 J. P. Jost and H. V. Rickenberg, Ann. Rev. Biochem. 40, $741 \cdot[1971]$.

n Y. Takai, H. Yamamura, and Y. Nishizuka, J. Biol. Chem. 249, 530 [1974].

n C. M. Duffus and J. H. Duffus, Experientia 25, 581 [1969].

23 C. J. Pollard, Biochim. Biophys. Acta 252, 553 [1971].

24 M. W. Nickells, G. M. Schaefer, and A. G. Galsky, Plant Cell Physiol. 12, 717 [1971].

2s M. Giannattasio and V. Macchia, Plant Sci. Lett. 1, 259 [1973].
* I. A. Potempa and A. G. Galsky, Plant Cell Physiol. 14, 989 [1973].

n D. Salomon and J. P. Mascarenhas, Z. Pflanzenphysiol. 63, 385 [1971].

28 B. Janistyn, Z. Naturforsch. 27 b, 872 [1972].

st H. N. Wood, M. C. Lin, and A. C. Braun, Proc. Nat. Acad. Sci. U.S. 69, 403 [1972].

* D. V. Basile, H. N. Wood, and A. C. Braun. Proc. Nat. Acad. Sci. U.S. 70, 3055 [1973].

31 R. Ockerse and L. M. Mumford, Naturwissenschaften 59, 166 [1972].

22 R. K. Ralph, P. J. A. McCombs, G. Tener, and S. J. Wojcik, Biochem. J. 130, 901 [1972].

a S. Kamisaka, N. Sakurai, and Y. Masuda, Plant Cell Physiol. 14, 183 [1973].

24 P. Wunderwald, G. Jurz, and G. Michal, Anal. Biochem. 59,468 [1974].

ss U. Kull, Bot. Studien (Jena) 19, 1 [1972].

s4 Ch. Mailänder and U. Kull, Naturwissenschaften 60, 479 [1973].

27 U. Kull and F. Hoffmann, Biologia plantarum, in press.

20 U. Kull and R. Büxenstein. Phytochemistry 13, 39 [1974].

sv N. Amrhein, Z. Pflanzenphysiol. 72, 249 [1974].

40 W. Hartung, Z. Pflanzenphysiol. 68, 329 [1973].

4 D. Rast. R. Skrivanova, and R. Bachofen, Phytochemistry 12, 2669 [1973].

a M. Giannattasio, E. Mandato, and V. Macchia, Biochem. Biophys. Res. Commun. 57, 365 [1974].

t $\mathrm{U}$. Kull and M. Höllwarth, Biochem. Physiol. Pflanzen 166, $105[1974]$.

4 G. M. Polya and A. R. Ashton, Plant Sci. Lett. 1, 349 [1973]

W G. M. Polya, Proc. Nat. Acad. Sci. U.S. 71, 1299 [1974]. 